\title{
Drug related problems associated with the psychoactive drugs used on geriatric, hospitalized patients
}

\author{
Ortega López Irma Leonor ${ }^{1, *}$, Verdecia Rosés Miguel Ernesto ${ }^{2}$ \\ ${ }^{1}$ Pharmacy Department, Orient University, Santiago de Cuba, Cuba, " "Saturnino Lora" Hospital of \\ Santiago de Cuba, Cuba
}

\begin{abstract}
A prospective study was carried out, to identify the drug related problems and to prevent or to solve the negative outcomes associated with medication of the geriatric patients that consumed psychoactive drugs, who were hospitalized. The study was carried out according to the DADER Method of Pharmacotherapy Monitoring, adapted to the Hospital's environment and the theoretical rationale of the Third Consent of Granada was assumed, for the considerations related to the drug related problems and the negative outcomes associated with medication. Thirty five patients were included whose ages ranged between the 60 and 90 years. Thirty six negative associated outcomes were identified, in 34 patients that represented $97.14 \%$ incidence. A prevalence of the negative outcomes associated with the necessity was observed, followed by those associated with the security. The inadequate drug uses was the drug related problem that prevailed in the sample. The psychoactive drugs that were related with these results were mainly the anxiolytics, meprobamate and the neuroleptics. Some $82.35 \%$ of the interventions were accepted, achieving resolution of $47.06 \%$ of the negative outcomes associated with medication.
\end{abstract}

Uniterms: Medication/associated negative outcomes. Psychoactive drugs/geriatric use. Geriatric patients/ use of psychoactive drugs.

Foi realizada uma pesquisa de intervenção, prospectiva, a fim de identificar problemas relacionados aos medicamentos e evitar ou resolver resultados negativos daí decorrentes, em pacientes idosos que faziam uso de medicamentos psicotrópicos e que foram internados. O estudo foi realizado de acordo com o método DADER para o acompanhamento farmacoterapêutico e assumiram-se os pressupostos teóricos do III Consenso de Granada, as considerações relacionadas com os problemas dos fármacos e os resultados negativos associados à medicação. Foram incluídos 35 pacientes com idades entre 60 e 90 anos. Trinta e seis RM foram identificados em 34 pacientes representando incidência de 97,14\% e a prevalência foi observada para os resultados negativos associados com a necessidade, seguidos por aqueles relacionados à segurança. $\mathrm{O}$ uso indevido de fármacos foi os problema mais frequente na amostra. Os psicofármacos mais implicados foram os ansiolíticos, meprobamato e neurolépticos. Das intervenções, 82,35\% foram aceitas, alcançando $47,06 \%$ de resolução dos resultados negativos associados à medicação.

Unitermos: Medicação/resultados negativos associados. Medicamentos psicotrópicos/uso em geriatria. Pacientes geriátricos/uso de psicotrópicos.

\section{INTRODUCTION}

The increase in life expectancy has determined progressive population aging, and Cuba is not exempt from this situation. Statistics show that older people represents more than the $15 \%$ of the population (Menchaca, 2011).

\footnotetext{
*Correspondence: O.L.I. Leonor. Departamento de Farmacia, Universidad de Oriente. Avenida Patricio Lumumba, s/n - Santiago de Cuba, Cuba. E-mail: irma@ent.uo.edu.cu
}

Between 81 and $85 \%$ of them consumes some drug (Peña, et al., 2003; Santana et al., 2007). Psychotropic drugs one of the groups of drugs that are prescribed more frequently in this population, represented in a higher frequency by benzodiazepines, antidepressants, and neuroleptics, which are used fundamentally against insomnia and anxiety (Aparasu, Mort, 2004; Aparasu, Mort, 2000).

Nowadays, one of the goals of medicine is to provide good health attention to all people older than 65 that inhabit and will inhabit our planet, they represent a large population 
sector. . The challenge for the $21^{\text {st }}$ Century is the improvement of life quality to "give our age more life and more years to our lives" (Werbin, 2006). An appropriate strategy to achieve this is the individualized pharmacotherapy monitoring through the development of Pharmaceutical Care, since Drug Related Problems (DRP) are common in the geriatric population, which are caused by polypharmacy, physiological changes related to age, the pharmacokinetics, and the pharmacodynamics. That is why, very general guidelines should be avoided, and individualized strategies should be used, which should be the best for every patient and every situation, where pharmacist-physician-patient communication and individualized pharmacotherapy monitoring are the most important.

\section{METHODS}

A prospective and intervention research was carried out with the purpose of identifying the DRP and preventing or solving the negative outcomes associated to them. This research was carried out with aged patients that consumed psychotropic drugs and that were hospitalized in the Intern medicine service of the Saturnino Lora Hospital, in Santiago de Cuba; in the period of four months.

The DADER method was used for the Pharmacotherapy Monitoring (Sabater et al., 2007), adapted to the Hospital's environment (Faus et al., 2008), and the theoretical methods that were used were the ones proposed by the Third Grenada Consensus, 2007 (Comité de Consenso, 2007). We carried out the steps listed below:

- The participation of pharmacists in the clinical sessions of internal medicine

- The participation of pharmacists in the pass with their health care plan

- Daily updated medication to the patient

- Interviewing the patient and their caregivers

- Resolve queries generated daily about drug therapy in the hospital service.

- Inform the patient about their medication during hospitalization and especially on hospital discharge, including information about the need to continue with the monitoring program for community pharmacists.

- Inform the health care team about the drug continuously, even after hospital discharge the patient.

\section{Pharmacotherapy follow-up to develop the following stages were followed}

\section{Service offer}

The offer of the service is performed from the Phar- macy Department; the Department of Internal Medicine, pointing out the interest of geriatric consumers including psychiatric drugs. For patient choice and service objectives of Pharmacotherapy follow-up, we took into account the medical criteria established by the heads of Internal Medicine.

After the doctor decided to include prospective patients in the study, informed consent was sought from the patient or caregiver, after explaining the guarantee of confidentiality of personal information, the purpose and usefulness of research to get the most benefit of pharmacotherapy with the least possible risk. Consent for participation was obtained by writing in the presence of the caregiver.

\section{Pharmaceutical Interview}

The first interview was conducted after observing the physician's assessment of income. Before the interview, the pharmacist should know the patients condition and have information about their medical history to detect indications of psychotropic drugs, and avoid unnecessary questions. In this interview emphasis took place on medication before hospitalization (which medicines were brought from home to hospital and which continued to take, or which suspended). This allowed the detection of drugs administered by self-medication and drug imposed for health problems suffered by the patient hospitalization. During the interview the presence of the caregiver was allowed, not only because in the hospital the patient can see his altered state of consciousness, but because it provides relevant information and actively involves in patient care while hospitalized, in addition to the characteristics the elderly patient. This moment became an opportunity to educate the patient and caregiver.

The information obtained was supplemented by medical records and nursing records. This information was updated through pharmacist participation in clinical sessions and the hall pass. Medical records and nursing records were consulted regularly. This allowed the development, in the most updated possible pharmacotherapeutic history of the patient during their hospital stay.

\section{Status report}

How the hospitalized patient was evolving and the many states of affairs during their hospital stay as well because of a limitation in the hospital, the patient can not give all the necessary information about their health problems and medication, to improve the record, this was supplemented with data from the daily review of medical records, nursing logs. 


\section{Phase of study}

The study focused primarily on the diagnosis of the incoming patient, which determines the main performance of the health team to treat the patient. From the established medical intervention, the pharmacist determined how the drug could contribute to the objectives pursued by the health team during the hospital stay. In the event that the use of psychotropic medication was detected by self-medication or a medical indication was reported prior to the doctor taking this into account in the procedures to follow in the pharmacotherapy. In this phase we studied the health concerns of the patient (or caregiver), related to the reason for admission, principal diagnosis, secondary diagnoses.

\section{Evaluation Phase}

We performed as quickly as possible, not only for the rapid evolution of the patient (which can vary in hours or minutes depending on the particular clinical situation of the case), but it should also meet the expectations of the health team, so justifying the presence of a pharmacist in the hospital service.

After identification of potential negative outcomes associated with medication (NOM) in the patient, they were studied with other pharmacists, before their approach to service practitioners.

\section{Intervention phase}

We designed an action plan that took into account the best possible strategy to solve the NOM, and therapeutic goals to achieve in the short, medium and long term, according to the health care team, patient and their caregivers.

Interview with the patient and results of pharmaceutical interventions: In the hospital, the constant presence of doctors and nurses allowed rapid communication that facilitated the resolution of NOM, but presented the NOM limiting those associated with the use of drugs indicated by other non-specialists of the hospital.

In addition to educational interventions during the hospital stay, each patient or caregiver was given the report on hospital discharge following the steps proposed for written communication between professionals, to resolve potential NOM in the community pharmacy. This format included the following points: 1) patient presentation; 2) medications administered during hospitalization; 3) parameters, signs or symptoms related to the medication to determine the patient's progress and to be assessed after discharge; 4) trial pharmacist (also included here is the need to educate to avoid self-medication and a problem with the patients previous medication must be taken into account, and 5) dismissal by the doctor responsible for the patient and the pharmacist who made SFT.

Medical intervention were used to evaluate the patient's pharmaceutical monitoring results, NOM was used as an indicating element for the solution or prevention.

The classification listed below was used:

- $\quad$ Solved NOM: It's when the NOM is solved whether the pharmaceutical intervention is accepted or not.

- Not solved NOM: It's when the NOM is not solved whether the pharmaceutical intervention is accepted or not.

- $\quad$ Prevented NOM: When a high probability of negative results due to medication were expected, by the patient's manipulation to mask the negative results.

\section{RESULTS}

In this research 35 patients, between 60 and 90 years old were included, where 36 NOM were identified in 34 patients, which represented a $97.14 \%$ incidence. So, every patient was probably exposed to $1.06 \mathrm{NOM}$. A prevalence of the negative results associated to need was observed with $50 \%$, followed by the ones associated with safety with $38.89 \%$, being the effectivity associated problems represented by $11.11 \%$.

In the Table I, are reflected the NOM and the DRP that caused the problems mentioned previously, specifying the drugs most implicated in each case.

The effect of the inappropriate drug was seen in 50\% of the patients, and $27.78 \%$ of them was related to anxiolytic use, and $13.89 \%$ was related to meprobamate. To a minor extent, amitriptyline, thioridazine and phenobarbital were used with no need in some patients, the inappropriate prescription being detected as a cause in the last two.

In the cases where non quantitative ineffectiveness was detected (11. 11\%), the cause was the drug interaction (phenobarbital /nifedipine; diazepam/phenytoin), which led in both cases to subtherapeutical levels of the drugs (phenobarbital and phenytoin) with the consequent therapeutical failure.

Any negative outcomes were not detected associated to the quantitative ineffectiveness and safety.

The non-quantitative safety problem was detected in $38.89 \%$ of the patients, being the neuroleptics and antiepileptics; with 13.89 and $8.33 \%$ respectively, the principal representatives, which had the adverse drug effects as a cause. The interaction between drugs was the fundamental cause of the appearance of non quantitative safety, representing $57.14 \%$ of the total cases detected, with the interaction of phenytoin with nifedipine the highest incidence. The likelihood of extrapyramidal effects, was probably related to the use of haloperidol in $13.89 \%$ of patients 
TABLE I - Incidence of DRP according to the type of NOM

\begin{tabular}{|c|c|c|c|c|}
\hline \multirow[t]{2}{*}{ Type of NOM } & Implicated drugs & \multicolumn{2}{|c|}{ NOM's Incidence } & \multirow[t]{2}{*}{$\mathrm{DRP} /$ references } \\
\hline & & \# & $\%$ & \\
\hline $\mathbf{A}$ & Not found & 0 & 0 & Not found \\
\hline \multirow[t]{5}{*}{$\mathrm{B}$} & $\begin{array}{c}\text { Chlordiazepoxide, Nitrazepam, } \\
\text { Diazepam }\end{array}$ & 10 & 27.78 & $\begin{array}{l}\text { Inadequate drug use (Beers, 1991; } \\
\text { Beers, 1997; Fick, et al, 2003) }\end{array}$ \\
\hline & Meprobamate & 5 & 13.89 & $\begin{array}{l}\text { Inadequate drug use/(Beers, 1991; } \\
\text { Beers, 1997; Fick, et al, } 2003 \text { ) }\end{array}$ \\
\hline & Amitriptyline & 1 & 2.78 & $\begin{array}{l}\text { Inadequate drug use/(Beers, 1991; } \\
\text { Beers, 1997; Fick, et al, 2003) }\end{array}$ \\
\hline & Thioridazine & 1 & 2.78 & Inadequate prescription (Fick, et al, 2003) \\
\hline & Phenobarbital & 1 & 2.78 & $\begin{array}{c}\text { Inadequate prescription/ } \\
\text { (Armijo, 1998; Zarranz,, 1996) }\end{array}$ \\
\hline \multirow[t]{2}{*}{$\mathrm{C}$} & Phenobarbital/Nifedipine & 2 & 5.56 & Drug Interaction \\
\hline & Diazepam/Phenytoin & 2 & 5.56 & Drug Interaction/ (MINSAP, 2006) \\
\hline $\mathbf{D}$ & Not found & 0 & 0 & Not found \\
\hline $\mathrm{E}$ & Not found & 0 & 0 & Not found \\
\hline \multirow[t]{8}{*}{$\mathbf{F}$} & Haloperidol & 5 & 13.89 & Probability of adverse effect \\
\hline & Meprobamate & 1 & 2.78 & Probability of adverse effect \\
\hline & Phenytoin/Nifedipine & 3 & 8.33 & $\begin{array}{c}\text { Drug Interaction/(Garcia, et. al., 1998; } \\
\text { MINSAP, 2006) and probability } \\
\text { of adverse effect }\end{array}$ \\
\hline & Meprobamate/ Nitrazepam & 1 & 2.78 & $\begin{array}{l}\text { Drug Interaction/(MINSAP, 2006) and } \\
\text { probability of adverse effect }\end{array}$ \\
\hline & Haloperidol/Phenobarbital & 1 & 2.78 & $\begin{array}{l}\text { Drug Interaction/(MINSAP, 2006) and } \\
\text { probability of adverse effect }\end{array}$ \\
\hline & Trihexyphenidyl/Haloperidol & 1 & 2.78 & $\begin{array}{l}\text { Drug Interaction/(MINSAP, 2006) and } \\
\text { probability of adverse effect }\end{array}$ \\
\hline & Chlordiazepoxide/ Cimetidine & 1 & 2.78 & $\begin{array}{l}\text { Drug Interaction/(MINSAP, 2006) and } \\
\text { probability of adverse effect }\end{array}$ \\
\hline & Phenytoin/ Tolbutamide & 1 & 2.78 & $\begin{array}{l}\text { Drug Interaction/(MINSAP, 2006) and } \\
\text { probability of adverse effect }\end{array}$ \\
\hline Total & & 36 & 100 & \\
\hline
\end{tabular}

$\mathrm{A}=$ Untreated health problem; $\mathrm{B}=$ Effect of unnecessary medicine; $\mathrm{C}=$ Non quantitative ineffectiveness; $\mathrm{D}=$ Quantitative Ineffectiveness; $\mathrm{E}=$ Quantitative safety; $\mathrm{F}=$ Non quantitative safety.

being diagnosed in $2.78 \%$ of the Parkinson Syndrome's sample. One Stevens - Johnson syndrome was diagnosed which might be responsible for non quantitative safety in the use meprobamate.

Every patient was exposed approximately to a 1.76 DRP, since the detected or prevented NOM were associated with 44 DRP, which are reflected in the Table II. It is important to observe that the problems that were involved to a higher extent with negative results, was the inadequate drug use with a $36.4 \%$. The detection of the adverse drug reaction and the drug interaction, which provoked their manifestation or therapeutic ineffectivity, were the other
TABLE II - Incidence Of Psychotropic Related Problems

\begin{tabular}{lcc}
\hline \multirow{2}{*}{ DRP } & \multicolumn{2}{c}{ AFFECTED PATIENTS } \\
\cline { 2 - 3 } & $\#$ & $\mathbf{\%}$ \\
\hline Drug Interaction & 12 & 27.3 \\
Inadequate drug use & 16 & 36.4 \\
Inadequate prescription & 2 & 4.5 \\
Probability of adverse effects & 14 & 31.8 \\
\hline TOTAL & 44 & 100 \\
\hline
\end{tabular}


TABLE III - Physician's answer to the pharmacist suggestions in order to solve or prevent the NOM and their solution

\begin{tabular}{lcccccccc}
\hline \multirow{2}{*}{ Facultative answer } & \multicolumn{9}{c}{ NOM } & \multicolumn{2}{c}{ Total } \\
\cline { 2 - 8 } & \multicolumn{2}{c}{ Solved } & \multicolumn{2}{c}{ Non solved } & \multicolumn{2}{c}{ Prevented } & \multicolumn{2}{c}{} \\
\cline { 2 - 9 } & $\#$ & $\%$ & $\#$ & $\%$ & $\#$ & $\%$ & $\#$ & $\%$ \\
\hline Accepted intervention & 8 & 47.06 & - & - & 6 & 35.29 & 14 & 100 \\
Non accepted intervention & - & - & 3 & 17.65 & & & 3 & 100 \\
\hline Total & 8 & 47.06 & 3 & 17.65 & 6 & 35.29 & 17 & 100 \\
\hline
\end{tabular}

causes that could have provoked a NOM with a higher frequency; represented respectively with a $31.8 \%$ and $27.3 \%$.

The psychotropic agents that provoked the NOM were, in first place, the anxiolytics (diazepam, nitrazepam, chlordiazepoxide) with a $36.11 \%$, followed by neuroleptics (haloperidol, thioridazine) with $22.22 \%$ and the use of meprobamate being found with a $19.44 \%$ incidence.

Interventions to resolve the effect of unnecessary drugs associated with inadequate drug use was made directly to the patient or caregiver through educational interventions. Similarly in the case of the NOM associated with the non-quantitative pharmacotherapeutic safety were monitored and only the physician intervention was performed in cases which manifested the NOM. Interventions being made by medical personnel only when the criterion was essential to resolve the NOM itself or in cases where the possibility of high expression was presented and high risk to the patient.

Seventeen interventions by Physician were carried out, where the $82.35 \%$ of them was accepted, which allowed $47.06 \%$ of the NOM to be solved (Table III).

The none acceptation of the interventions happened in $17.65 \%$ of the cases, having as a basis the existence of other elements in the patient that could have led to the detected health problem or of a previously imposed therapy, which should have been evaluated by the specialist.

Many educative interventions were done the day before the patients were going home to $100 \%$ of the ones researched. The therapy that every patient should continue and the possible non-compliance risks was analyzed. How to conserve the drugs and what to do in case of forgetting one dose was explained. The risks of self-medication were emphasized.

\section{DISCUSSION}

In relation to the NOM incidence in the sample, the results have to do with the ones of other researches (Blakey, Hixson-Wallace, 2000), where approximately 1.24 NOM per patient has been found, with a huge incidence of the effect of unnecessary medicine use on aged people.
Our study revealed that $45.71 \%$ of the patients were treated with psychoactive drugs potentially inappropriate use in geriatrics, independent of disease or condition. The most commonly inappropriately prescribed medication was chlordiazepoxide, diazepam (27.78\%) and meprobamate $(13.89 \%)$. Other study reveal values similar to those identified in relation to the use of potentially inappropriate medication (Beers, 1991; Beers, 1997; Stuch et al., 1994; Pardo et al., 2003; Bandrés et al., 2008), which exposes the elderly to unnecessary risks such as adverse effects of a worsening of the quality of life, increased hospitalizations and increased health spending (Jano et al., 2007).

The use of phenobarbital in epileptic patients who were seizure free for over five years was considered unnecessary, so it could be suppressed with the drug therapy based on publications that they refer (Armijo, 1998; Zarranz, 1996). In the other patient the effect of unnecessary medicine (thioridazine) was detected, they suffered severe hypertensive cardiac disease, which is contraindicated (MINSAP, 2006).

The interaction between diazepam and phenytoin possibly was responsible for non quantitative ineffectiveness detected in $5.56 \%$ of the patients. By removing the benzodiazepine adequate seizure control was achieved. Several studies show that serum levels of phenytoin may decrease or increase when this drug is used concomitantly with diazepam. Diazepam is one example of a drug that is extensively metabolized by CYP2C19 and could potentially influence phenytoin elimination by acting as an alternate substrate for this isoenzyme (Murphy, Wilbur, 2003).

The combination of phenobarbital/nifedipine may lead to non quantitative ineffectiveness; this is explained taking into account that phenobarbital causes an increase in the activity of the enzyme induction of synthesis of cytochrome $\mathrm{P}-450$, cytochrome $\mathrm{P}-450$ reductase and other enzymes involved in the metabolism of nifedipine. In addition to phenobarbital increases hepatic blood flow (MINSAP, 2006).

The quantitative insecurity because of the likelihood of increased adverse effects of phenytoin inter- 
action with nifedipine occurred in $8.33 \%$ of patients which can be explained by increased circulating levels of phenytoin can presented in patients treated with nifedipine, by reducing the hepatic first, and compete with this by binding to plasma proteins (Garcia et. al., 1998; MINSAP, 2006).

The prevalence of psychotropic drug use for the treatment of insomnia could have been caused by the fact that this is very frequent in aged people, because of the minor need of sleep at this age, and because of the presence of chronic illness (with symptoms of pain, dyspnea, polyachiuria), the use of drugs that can alter not only the quantity, but also the quality of sleep; and also psychiatric illnesses like depression, anxiety, and dementia (Gil, 1996). It is said, that the most used drugs in aged people are psychotropics ((Mattiussi, 2004; Aparasu, Mort, 2004; Aparasu, Mort, 2000). It is important to say that $33.33 \%$ of the patients were treated with drugs that could cause insomnia, and the $46.67 \%$ were treated with diuretics, that sometimes, were supplied in the afternoon or in the evening, causing sleep's alterations due to night polyuria.

The use of inadequate drugs, of which the DRP with a high frequency, was related to the use of chlordiazepoxide, diazepam, nitrazepam, amitriptyline and meprobamate. According to reports (Merck, 1999; Fick et al., 2003), the anxiolytic of half long duration are not the most adequate drugs for aged people, because they cause long term sedation, increasing the risk of falls and fractures. In the same way, amitriptyline and chlordiazepoxide, due to their anticholinergic and sedating properties, are not the best choice for elderly patients. Meprobamate produces sedation relatively easily, that is why all the drugs were inadequately used in the patients of the sample (Beers, 1997; Fick et al., 2003; Pardo et al., 2003; Bandrés et al., 2008).

Old people have a bigger risk of toxicity, and of developing dependence on some drugs, especially with the long duration like benzodiazepines. That is why they should be avoided. So, the half duration benzodiazepines will be carefully used, choosing the minimal doses and the drug of minor activity (Gil, 1996; Merck, 1999).

The prescription of barbiturates in old people should be reserved for convulsion treatment, because they provoke more adverse effects than the majority of other hypnotic and sedatives in these people, and also produce dependence more easily; besides, they may precipitate depression states (Merck, 1999) that occasionally justify the increase of the number of drugs in the patient's pharmacotherapy. The barbiturates use in aged patients has many disadvantages, such as: tendency to developing hab- its, severe drug interactions, enzymatic hepatic problems and rebound phenomena like agitation and delirium. For all these reasons, this is contraindicated in the insomnia treatment (Gil, 1996)

It is known that the probability of the detection of the adverse drug reaction increases when people get older, some authors refer that adverse reactions are duplicated in these patients (Werbin, 2006). Among the adverse effects of the medication to aged people, is Parkinson's induced by drugs (Preston et al., 2006), which was detected in a patient and attributed to the haloperidol use. This is the reason why the basis pathologies must be taken into account.

The factors of the adverse drug reaction risk in aged patients depend on many reasons, among them, advanced age, high number of drugs, higher doses and long treatments, previous adverse reactions, underlying illnesses, inadequate clinical valuation, wrong therapeutical accomplishment, self-medication and altered nutritional condition (Werbin, 2006; De la Serna, 2000). The majority of these factors were found in the sample.

The psychopharmacologic treatment should be based on a careful diagnostic, and it should be used as long as the relationship benefit- risk is clearly favorable, trying to suspend the drugs as soon as the patient gets better, except for the cases where relapses must be prevented (Werbin, 2006).

In the United Kingdom (Vicent et al., 2001), 11\% of the hospitalized patients suffers an adverse effect; and the half of them could have been prevented. We agree with this approach because with the obtained results it can be said that with an integral work of the health team, it is possible to avoid most of the DRP that lead to NOM, where educative interventions to the patients and the health team are very important.

There are few prospective researches about pharmacological interactions in elderly people. A research shows that $40 \%$ of the ambulatory patients are at risk of suffering the consequences of pharmacological interactions, and $27 \%$ of them are potentially severe (Merck, 1999). These reports exceed the ones detected in this research, where a $34.28 \%$ were exposed to a drug interaction; the $33.33 \%$ of them were responsible for a therapeutical ineffectivity, and $66.7 \%$ increasing the probability of the adverse drug reaction.

The achieved results with the proposed interventions by the Physician corresponded to the ones achieved in similar researches, where the acceptation of the interventions was represented the following way: 74.7 (Bonilla et al., 2009), 88. 8 (Galindo et al., 2003), and 91\% (Garzas et al., 2003). 


\section{CONCLUSIONS}

A prevalence of the negative outcomes associated with the necessity was observed, followed by those associated with the security. The inadequate drug use and the probability of adverse effects were the drug related problems that prevailed in the sample. The psychoactive drugs that were related with these results in the main were anxiolytics, neuroleptics and meprobamate.

\section{REFERENCES}

APARASU, R.R.; MORT, J.R. Prevalence, correlates, and associated outcomes of potentially inappropriate psychotropic use in the community-dwelling elderly. Am. J. Geriatr. Pharmacother., v.2, n.2, p.102-111, 2004.

APARASU, R.R.; MORT, J.R. Inappropriate prescribing for the elderly: Beers criteria-based review. Ann. Pharmacoter., v.34, n.3, p.338-346, 2000.

ARMIJO, J.A. Fármacos antiepilépticos y anticonvulsivos. In: FLÓREZ, J.; ARMIJO, J.A.; MEDIAVILLA, A. (Eds.). Farmacología Humana. 3.ed. Barcelona: Masson, S.A., 1998. Sección IV, p.489-512.

BLAKEY, S.; HIXSON- WALLACE, J. Clinical and economic effects of Pharmacy Services in a Geriatric Ambulatory Clinic. Pharmacother., v.20, n.10, p.1198-1203. 2000.

BEERS, M.H; OUSLANDER, J.G.; ROLLINGER, I.; REUBEN D.B.; BROOKS, J.; BECK J.C. Explicit criteria for determining potentially inappropiate medication use on nursing home residents. Arch. Intern. Med., v.151, p.18251832, 1991.

BEERS, M.H. Explicit criteria for determining potentially inappropriate medication use by the elderly. Arch. Intern. Med., v.157, 1531-1536, 1997.

BONILLA, P.; GARCÍA, A.; COMPELLAS, P.; GARCÍA, P. Detección de problemas relacionados con medicamentos en antimicrobianos. Aten. Farm., v.11, n.3, p.181-189, 2009.

BRANDÉS, A.C.; BELOQUI, J.J.; VILLAR I.; IZUEL-RAMI, M. Aplicación de los criterios de Beers al ingreso en dos servicios de medicina interna. Aten. Farm., v.10, n.5, p.285293, 2008.
COMITÉ DE CONSENSO: GIAF-UGR, GIFAF-USE, GIFUGR. Tercer Consenso de Granada sobre Problemas Relacionados con Medicamentos (PRM) y Resultados Negativos asociados a la Medicación (RNM). Ministerio de Sanidad y Consumo. Ars Pharm., v.48, n.1, p.5-17, 2007.

DE LA SERNA, I. Utilización de psicofármacos en el anciano. Interacciones y efectos secundarios. Rev. Psiquiatría Fac. Med. Barna, 2000, v.27, n.5, p.292-296. Available at: $<\mathrm{http}$ ://www.nexusediciones.com/pdf/psiqui2000_5/ps-275-009.pdf $>$. Accessed on: 13 Apr. 2010.

FAUS, M.J.; AMARILES, P.; MARTÍNEZ, F. Atención Farmacéutica conceptos, procesos y casos prácticos. Madrid: Ergon, 2008. p.98-103.

FICK, D.M.; COOPER, J.W.; WADE, W.E.; WALLER, J.L.; MACLEAN, J.R.; BEERS, M.H. Updating the Beers Criteria for Potentially Inappropriate Medication Use in Older Adults. Arch. Intern. Med. v.163, n.8, p.2716-2724, 2003.

GALINDO, C.; OLIVÉ, M.; LACASA, C.; MARTÍNEZ, J.; ROURE, C.; LLADÓ, M.; ROMERO, I.; VILI, A. Pharmaceutical care: pharmacy involvement in prescribing in acute- care hospital. Pharm. World Sci., v.25, n.2, p.5664, 2003.

GARCÍA, A.G., MICHELENA, P., GANDÍA, L. Fármacos antagonistas del calcio. In: FLÓREZ, J.; ARMIJO, J.A.; MEDIAVILLA, A. (Eds.). Farmacología humana. 3.ed. Barcelona: Masson, S.A., 1998. Sección V, p.637-648.

GORGAS, M.; ODENA, E.; PASTOR, F. Pharmaceutical care: for drug related problems in patients. Farm. Hosp., v.27, n.5, p.280-289, 2003.

GIL, P. Geriatría. In: FARRERAS, P.; ROZMAN, C. (Eds.). Medicina interna. 13.ed. Madrid: Mosby-Doyma Libros, 1996. Sección 10, p.1287-1299. (CD-ROM).

JANO, E.; APARASU,R. Healthcare outcomes associated with Beers' criteria. A systematic Review. Ann. Pharmacother., v.41, n.3, p.438-448, 2007.

MATTIUSSI, M. Prevalencia, correlación y efectos asociados al uso de psicotrópicos potencialmente inadecuados en ancianos de la comunidad. Medicina Geriátrica. 2004. n.p. Available at: <http://www.medicinageriatrica.com.ar/ cgi-bin/coranto/viewnews.cgi?id=EplAVAlukVWhVfDwB h\&tmpl=viewnews $>$. Accessed on: 13 Apr. 2010. 
MENCHACA, R. Cuba: Más ancianos y menos niños. In: Exclusivos. Cubahora Revista Informativa. Cuba. 2011. n.p. Available at: <http://www.cubahora.cu/index. php?tpl=buscar/vernot_buscar.tpl.html\&newsid_obj_ $\mathrm{id}=1026669>$. Accessed on: 04 Jan. 2011.

MERCK Manual. Tratamiento farmacológico en el anciano. 10.ed. Madrid, 1999. cap.304, n.p., (Edición del Centenario). (CD-ROM).

MINISTERIO DE SALUD PÚBLICA(MINSAP). Formulario Nacional de Medicamentos. 2.ed. Cuba: Ciencias Médicas, 2006, 554p.

MURPHY, A.; WILBUR, K. Phenytoin- diazepam interaction. Ann. Pharmacother., v.37, n.5, p.659-663, 2003.

PARDO, G.C.; OMS, A.M.; SERRA, M.J.; BENAVENT, B.R.; ARIÑO, B.S. Medicamentos inapropiados en geriatría, benzodiacepinas de acción prolongada. Aten. Farm., v.5, n.2, p.113-121, 2003.

PEÑA, M.A.; REDONDO, A.; GRONING, E. Consumo de medicamentos en anciano. Rev. Cubana de Med. Gen. Integr., v.19, n.3, 2003. Available at: <http:// http://scielo. sld.cu/scielo.php?pid=S086421252003000300007\&script =sci_arttext $>$. Accessed on: 04 Jan. 2011.

PRESTON, J.; O’NEAL, J.H.; TOLEGA, M.C. Handbook of clinical psychopharmacology for therapists. 2.ed. p. 202203. Apud WERBIN, A. Psicofarmacología y polifarmacia en la tercera edad. Gerontología, n.p., 2006. Available at: http://weblog.maimonides.edu/gerontologia2006/2006/03/ psicofarmacologia_y_polifarmac.html. Accessed on: 20 May 2010.
SABATER, D.; SILVA, M.M.; FAUS, M.J. Método Dáder: guía para el seguimiento farmacoterapéutico. 3.ed. Granada: Grupo de Investigación en Atención Farmacéutica, 2007. $128 \mathrm{p}$.

SANTANA, L.; SANTANA, F.; LUNA, C.; OLIVA, T.; ROSALES, R., GONZÁLEZ, R. Uso de medicamentos en edad geriátrica. Policlínico Universitario “Antonio Maceo”. Revistaciencias. Com, Cuba, 2007. n.p. 2007. Available at: http://www.revistaciencias.com/publicaciones/ EEAVZZypVyfYHbgsGZ.php. Accessed on: 04 Jan. 2011.

STUCH, A.E.; BEERS, M.H.; STEINER, A. ARONOW, H.U. Inappropiate medication use in community- residing older persons. Arch. Intern. Med., v.154, p.2195-2200, 1994.

VICENT, C.; NEALE, G.; WOLOOSHYNOWYCH, M. Adverse events in British Hospitals: preliminary retrospective record review. BMJ, v.322, n.7285, p.517519, 2001.

WERBIN, A. Psicofarmacología y polifarmacia en la tercera edad. Gerontología. 2006. n.p. Available at: <http:// weblog.maimonides.edu/gerontologia2006/2006/03/ psicofarmacologia_y_polifarmac.html.>. Accessed on: 20 May 2010.

ZARRANZ, J. Neurología. In: FARRERAS, P.; ROZMAN, C. (Eds.). Medicina interna. 13.ed. Madrid: Mosby-Doyma Libros, 1996. Sección 12, p.1458-1471. (CD-ROM).

Received for publication on $2^{\text {nd }}$ June 2011 Accepted for publication on $24^{\text {th }}$ May 2012 